Annals of Plant and Soil Research 23(2): 156-163 (2021)

https://doi.org/10.47815/apsr.2021.10049

\title{
Eco-friendly management of Colletotrichum gloeosporioides, incitant of fruit rot of guava (Psidium guajava)
}

\author{
H.K. CHOURASIA* AND GYANA NAND JHA \\ Applied Microbiology and Plant Pathology Laboratory, University Department of Botany \\ T.M. Bhagalpur University, Bhagalpur-812 007, Bihar (India)
}

Received: March, 2021; Revised accepted: April, 2021

\begin{abstract}
The present study was conducted at Tej Narayan Banaili College, T.M. Bhagalpur University, Bhagalpur, Bihar during 2015-2017 to evaluate the efficacy of 8 medicinal plants viz. Datura stramonium (datura), Curcuma longa (turmeric), Azadirachta indica (neem), Zingiber officinale (ginger), Allium sativum (garlic), Ocimum sanctum (tulsi), Nyctanthus arbortristis (harsringar) and Piper betle (betel/paan) and 4 bioagents viz. Trichoderma harzianum, T. viride, Gliocladium virens and Chaetomium globosum against Colletotrichum gloeosporioides (Penz.) Penz. \& Sacc., an incitant of fruit rot disease of guava (Psidium guajava Linn.). A maximum inhibition of mycelial growth of pathogen was recorded in garlic clove extract (80\%) followed by betel leaf extract (76\%), turmeric rhizome extract (74\%), neem leaf extract (70\%) and ginger rhizome extract (64\%). Harsringar leaf extract was found as the least effective (56\%). In pre-and post-inoculation tests, all the phytoextracts were found significantly superior in reducing Colletotrichum rot severity on 7 days after treatments as compared to control. Garlic clove extract again proved highly effective in reducing fruit rot severity after 7 days after inoculation in both pre - and post - inoculation treatments. In vitro dual culture experiments, maximum growth inhibition was recorded with $T$. viride (76.5\%) followed by G. virens (72.2\%), $T$. harzianum $(67.6 \%)$ and least inhibition by C. globosum (44.7\%) In both pre - and post- inoculation treatments with antagonists, maximum DRI (disease reduction index) was noticed with C. globosum (69.2 and 62.4\%) followed by T. harzianum (51.9 and 56.7\%), G. virens (44.8 and 46.9\%) and least with T. viride (38.1 and 35.4\%). The rot incidence at $8 D A I$ (days after inoculation) was significantly higher than that at 4 DAI. The hot water fruit dip treatment at $50^{\circ} \mathrm{C}$ for 5 min was found best for controlling the rot without hampering the fruit quality.
\end{abstract}

Key words : Management, Colletotrichum gloeosporioides, fruit rot, guava

\section{INTRODUCTION}

Guava fruit suffers with a number of postharvest rots caused by Alternaria alternata, Aspergillus niger, Botryodiplodia theobromae, Colletotrichum gloeosporioides, Pestalotia psidii, Penicillium expansum and Rhizopus stolonifer (Ray et al., 2007; Singh et al., 2008; Chourasia and Jha, 2010). Among various post-harvest rots of guava, fruit rot incited by $C$. gloeosporioides is a major disease in Bihar, having a pivotal role in guava cultivation with 29,000 ha area and annual production of 4,107 million tones in 2018 - 2019 (Anonymous, 2019). Under northern conditions, this disease appears in severe form during rainy season as compared to winter season crop. The genus Colletotrichum has occupied one of the top 10 fungal plant pathogens because of its broad host range, devastation of essential crops and importance as a model post-harvest pathogen (Munir et al., 2016). Colletotrichum has been termed "a catalogue of confusion", due to its perpetually changing taxonomy, limited morphological differentiation among species, rare presence of sexual stages and variation in pathogenicity and cultural morphology (Cannon et al., 2012; Johnson, 2018). Colletotrichum spp. vary in their infection strategies on different hosts and species, and may preferentially infect different tissues (De Silva et al., 2017). This soil borne pathogen ( $C$. gloeosporioides) may produce toxic metabolites whose ingestion by human beings may lead to several disorders known as mycotoxicoses (Li et al., 2017). Although various fungicides have shown promosing results in controlling post-harvest fruit rot pathogens of guava, but the development of fungicidal resistance in pathogens, contamination of food by toxic residues, resurgence of pest and detrimental effects on non-target organisms are some of the major constraints in disease management. Biological control has emerged as a potential strategy to combat major post-harvest fruit rot pathogens. 
Successful biological control systems commonly employ naturally occurring antagonistic fungi and bacteria that are effectively reduce activities of plant pathogens (Cook, 1993;Shishido et al., 2005). Trichoderma spp. are the filamentous soil borne mycoparasitic fungi commonly used as bio-fungicides for the management of a wide range of soil borne plant pathogens and some have a plant growth promotion ability (Tasiwal et al., 2009; Ozbay et al., 2014). During the last few decades they have enabled non-chemical plant disease management system and organic agriculture in particular (Woo, 2006; Pan and Bhagat, 2007). Several plant species have also shown inhibitory activities against fruit rot pathogens (Lakpale et al., 2008; Panchal and Patil, 2009). In the present investigation, some eco-friendly methods were tried for the management of Colletotrichum gloeosporioides fruit rot of guava with some phytoextracts, biocontrol agents especially Trichoderma harzianum, T. viride, Gliocladium virens and Chaetomium globosum, and hot water treatment.

\section{MATERIALS AND METHODS}

Pathogenicity test and identification of incited rot:

The pathogencity was proved by inoculating the injured healthy fruits with spore suspension $\left(1 \times 10^{6}\right.$ spores $\left./ \mathrm{ml}\right)$ of Colletotrichum gloeosporioides isolated from rotted guava fruits, collected randomly from retail fruit markets and cold storages of Bhagalpur during 2015 - 2017. Healthy fruits with pedicels were injured several times with the help of a fine sterilized needle. A cotton swab soaked with spore suspension was placed on the injured area. Fruits were then covered with perforated polythene bags and incubated at $25+1^{\circ} \mathrm{C}$ for 7 days. The cotton swab was moistened with sterile distilled water whenever needed. Typical symptoms of the rot were recorded after 7 days. The identification of C. gloeosporioides was done with the help of identification key of imperfect fungi (Barnett and Hunter, 1972).

\section{Efficacy of phytoextracts:}

Eight medicinal plants viz., datura (Datura stramonium L), turmeric (Curcuma longa L.), neem (Azadirachta indica A. Juss), ginger (Zingiber officinale Rose), garlic (Allium sativum
L.), tulsi (Ocimum sanctum L.), harsringar (Nyctanthes arbortristis L.) and betel (Piper betle L.) were evaluated against $C$. gloeosporioides by following poisoned food technique (Nene and Thapliyal, 1979). Each of the phytoextracts was thoroughly mixed in sterilized $100 \mathrm{ml}$ PDA medium under aseptic condition. The medium was supplemented with streptomycin sulphate @ $50 \mathrm{ppm}$ to prevent bacterial contamination. The plates were inoculated with a $5 \mathrm{~mm}$ disc of 7 days old culture of test pathogen along with suitable control. Each treatment was replicated four times. The inoculated plates were incubated at $28 \pm 1^{\circ} \mathrm{C}$. Observations on growth inhibition and sporulation of test fungi were recorded after 7 days of incubation (Panchal and Patil, 2009). The sporulation was recorded in a I - 5 scale: $1=$ no spore, $2=$ poor $(1-7), 3=$ moderate $(8-25)$, $4=\operatorname{good}(26-50)$ and $5=$ excellent $(>50$ conidia per microscopic field).

\section{Pre-inoculation method:}

The healthy, semi-ripe, uniform size guava fruits were surface sterilized by dipping in $\mathrm{HgCl}_{2}(1 \%)$ for 1 min followed by three washings with sterile distilled water. The spores from 7 days old cuture of $C$. gloeosporioides were scrapped with the sterile needle and mixed in $200 \mathrm{ml}$ distilled sterile water. The fruits were first dipped in phytoextracts (10\%) separately and then inoculated after $12 \mathrm{hr}$ with the pathogen. The fruits were injured with sterilized cork borer at stem-end and dipped in spore suspension $\left(10^{6} \mathrm{spores} / \mathrm{ml}\right)$ for $2 \mathrm{~min}$ and air dried for $15-20$ min. The inoculated and un-inoculated fruits were placed individually in sterilized polythene bags. A piece of sterilized moist absorbent cotton swab was placed inside the bag and mouth of the bag was loosely tied. The bagged fruits were incubated at $28+1^{\circ} \mathrm{C}$ for 7 days. Each treatment was replicated eight times.

\section{Post-inoculation method:}

In post-inoculation treatment, the semiripe fruits were first inoculated with the pathogen and then treated with the phytoextracts. Further procedure was followed as mentioned earlier. In vitro evaluation of antagonists: Efficacy of four fungal antagonists viz. Trichoderma harzianum, T. viride, Gliocladium virens and Chaetomium globosum were tested by dual culture technique against $C$. gloeosporioides. Mycelial discs of 5 
$\mathrm{mm}$ diam cut from margin of 7 days old culture of the pathogen and fungal biocontrol agents were placed $6 \mathrm{~cm}$ apart on PDA (potato dextrose agar) in the same Petri plate opposite to each other. Plates having only pathogen served as control. Each treatment was replicated thrice. The inoculated plates were incubated at $25 \pm 1^{\circ} \mathrm{C}$ in a BOD chamber. The per cent inhibition in growth of pathogen by biocontrol agents over control was calculated as Jat et al. (2008).

\section{Non-volatile metabolites:}

Hundred $\mathrm{ml}$ sterilized PDB (potato dextrose broth) filled in $250 \mathrm{ml}$ flasks incubated at $25 \pm 1^{\circ} \mathrm{C}$ for 15 days in a BOD chamber. The broth was filtered through three layered Whatman filter paper No. 42. Each filtrate was mixed with PDA separately (10\%) and autoclaved in flasks. The PDA was then poured aseptically into sterile Petri plates. After solidifying the PDA, the mycelial discs of $5 \mathrm{~mm}$ diam were cut from the margin of 7 days old actively growing culture of the pathogen and inoculated in the centre of the plates. Plates having only PDA without filtrate served as control. Each treatment was replicated thrice. The inoculated plates were incubated at $25 \pm 1^{\circ} \mathrm{C}$ in a BOD chamber. The per cent inhibition in mycelial growth of pathogen over control was derived.

\section{Volatile metabolites:}

The efficacy of volatile metabolites was studied by inoculation of the biocontrol agents and the pathogen with $5 \mathrm{~mm}$ disc of 7days old actively growing culture in separate Petri plates on PDA. Lids of Petri plates were removed and the Petri plate containing pathogen was inverted over the Petri plate containing biocontrol agent and sealed with adhesive tape (magic tape) under aseptic conditions. The control had same pathogen in both upper and bottom Petri plates. Inoculated Petri plates in triplicate were incubated at $25 \pm 1^{\circ} \mathrm{C}$ in a BOD chamber. The per cent inhibition in mycelial growth of the pathogen as compared to control was calculated.

\section{In vivo evaluation of antagonists:}

Antagonists studied in vitro were further tested with guava fruits. The healthy semi-ripe fruits were surface sterilized by dipping in $\mathrm{HgCl}_{2}$ solution $(0.1 \%)$ for $1 \mathrm{~min}$ followed by three washing with sterile distilled water and pricked up to the depth of $2 \mathrm{~mm}$, making 5 wounds/fruit. These fruits were separately inoculated by dipping them in a spore suspension $\left(10^{6}\right.$ spores $/ \mathrm{ml}$ ) for $2 \mathrm{~min}$. Spore suspension of each biocontrol agent was used as pre - as well as post - inoculation dip treatments. In preinoculation treatment, the fruits were first dipped in the spore suspension of biocontrol agents for $5 \mathrm{~min}$, air dried for $15 \mathrm{~min}$ and then inoculated with pathogen. In the post-inoculation treatment, the fruits were first inoculated with pathogen and then treated with biocontrol agents. Parallel controls with fruits dipped in sterile distilled water were run simultaneously. The interval between inoculations was of $12 \mathrm{hr}$. Each treatment was replicated thrice with 7 fruits per replication in a factorial randomized block design. The inoculated fruits were enclosed separately in pre- sterilized perforated polythene bags partially sealed with paper pins and incubated at $25 \pm 1^{\circ} \mathrm{C}$ and $90-100 \% \mathrm{RH}$. The number of wounds showing rot were recorded on 4 and 8 DAI (day after inoculation) and per cent rot incidence was calculated. The disease reduction index (DRI) was worked out as Sharma et al. (2008).

Hot water treatment: The effect of hot water treatment on the development of $C$. gloeosporioides fruit rot was studied at 45, 50 and $55^{\circ} \mathrm{C}$. The semi-ripe guava fruits were inoculated with pathogen $\left(10^{6}\right.$ spores $\left./ \mathrm{ml}\right)$ by stem end injury method and exposed to desired temp for 5 and 10 min along with control with a $12 \mathrm{hr}$ interval between inoculation and hot water treatment. All the fruits were placed separately in sterilized polythene bags along with sterilized moist cotton swab and bagged fruits were incubated at $28 \pm 1^{\circ} \mathrm{C}$. Each treatment was replicated eight times. Observations on the disease severity were recorded after 7 days of inoculation.

\section{RESULTS AND DISCUSSION}

Identification of rot symptom, pathogen and pathogenicity test

The rot symptom on guava fruit was identified by the appearance of whitish cottony growth which developed very fast as the fruit matures and pathogen soon covered the entire 
surface within a period of 3-4 days under humid weather. The skin of the fruit below the whitish cottony growth become soft and turned light brown to dark colour. The rot gradually extended deep into the fruit rendering the tissues black, soft and watery. The repeated isolation of $C$. gloeosporioides from rotten portions of the fruits proved pathogenicity in the test.

\section{Phytoextracts}

All the phytoextracts were found significantly superior in inhibiting the mycelial growth and sporulation of $C$. gloeosporioides over control (Table 1). A maximum inhibition was recorded in garlic clove extract $(10 \mathrm{~mm})$ with $80 \%$ inhibition over control. The next best treatments were obtained with betel (paan) leaf extract $(13 \mathrm{~mm})$, turmeric rhizome extract (15 $\mathrm{mm})$, neem leaf extract $(17 \mathrm{~mm})$ and ginger rhizome extract $(20 \mathrm{~mm})$ with $76 \%, 74 \%, 70 \%$ and $64 \%$ inhibition, respectively. Harsringar leaf extract was found as the least $(56 \%)$ effective. None of the phytoextracts supported sporulation which was abundant in control. Similar results on inhibition of $C$. gloeosporioides by betel leaf extract have been reported by Johnny et al. (2010). They stated that the antifungal properties of betel is due to the presence of a number of physiologically active compounds such as alkaloids / amides, propenylphenols, lignans, neolignans, terpenes, steroids, kawapyrones, piperolides, chalcones, flavones and flavanones. Jat et al. (2008) also found neem leaf extract as effective in inhibiting the mycelial growth of $C$. gloeosporioides causing banana fruit rot. Singh (2011) reported that the neem extract contains a high level of antifungal azadirachtin compound. Other researchers have reported similar results with different fruits using garlic clove extract (Shinde et al., 2016; Nurfatimma et al., 2018). According to Alemu et al. (2014), allicin, dially trisulphide and ajoene are the active compounds in garlic that give inhibitory activity against $C$. gloeosporioides in mango anthracnose. Lakpale et al. (2008) and Dissanayake et al. (2019) reported that extracts of several botanicals were highly effective in inhibiting mycelial growth and sclerotial production of different soil borne plant pathogens.

Table 1: Effect of phytoextracts (10\%) on mycelial growth of C. gloeosporioides and severity (\%) of guava fruit rot in pre-and post- inoculation tests

\begin{tabular}{|c|c|c|c|c|}
\hline Phytoextracts & Mycelial growth $(\mathrm{mm})$ & Growth inhibition (\%) & Pre-inoculation & Post-inoculation \\
\hline Betel (Paan) leaf extract & 13 & 76 & 10 & 14 \\
\hline Datura leaf extract & 21 & 62 & 12 & 16 \\
\hline Garlic clove extract & 10 & 80 & 7 & 11 \\
\hline Ginger rhizome extract & 20 & 64 & 16 & 21 \\
\hline Harsringar leaf extract & 27 & 56 & 17 & 25 \\
\hline Neem leaf extract & 17 & 70 & 14 & 18 \\
\hline Tulsi leaf extract & 22 & 61 & 14 & 17 \\
\hline Turmeric rhizome extract & 15 & 74 & 22 & 28 \\
\hline Control & 58 & 0 & 42 & 39 \\
\hline$C D(P=0.05)$ & 2.95 & & 2.76 & 3.35 \\
\hline CV (\%) & 8.25 & & 7.95 & 8.25 \\
\hline
\end{tabular}

${ }^{*}$ Figures were square root transformed before analysis

In pre- and post-inoculation tests, all the phytoextracts were found significantly superior in reducing the Colletotrichum rot severity on 7 days after treatment as compared to control (Table 1). In pre-inoculation treatment, a reduced rot severity was observed in guava fruits treated with garlic clove extract followed by betel, neem and tulsi leaf extracts. In postinoculation method, significant reduction in fruit rot severity was found with extracts of garlic, betel, datura, tulsi and neem. Extracts of turmeric rhizome and harsringar had least effect on development of fruit rot symptoms in both pre- and post - inoculation treatments.

\section{Efficacy of bioagents}

All the 4 biocontrol agents screened under dual culture experiments inhibited mycelial growth of C. gloeosporioides significantly over 
control. A maximum inhibition of growth (76.5\%) was recorded with $T$. viride followed by $G$. virens (72.2\%), T. harzianum (67.6\%) and least inhibition (44.7\%) by C. globosum (Table 2). $T$. viride and $G$. virens were statistically at per with each other in limiting C. gloeosporioides.

Table 2: In vitro antagonism (\% inhibition) by fungal biocontrol agents against C. gloeosporioides

\begin{tabular}{|c|c|c|c|}
\hline Biocontrol agents & Dual culture & Volatiles & Non-volatiles \\
\hline Trichoderma harzianum & 67.6 & 58.6 & 49.6 \\
T. viride & 76.5 & 64.2 & 57.7 \\
Gliocladium virens & 72.2 & 62.4 & 54.8 \\
Chaetomium globosum & 44.7 & 25.6 & 32.4 \\
Control & 0 & 0 & 0 \\
CD (P=0.05) & 2.27 & 2.35 & 2.3 \\
CV (\%) & 2.77 & 3.45 & 3.20 \\
\hline
\end{tabular}

${ }^{\star}$ Figures were square root transformed before analysis

Results of pre-inoculation experiments with antagonists were found significantly efficient in reducing fruit decay loss over control (Table 3). Chaetomium globosum retarded (69.2\%) the rot incidence most effectively. The next best antagonist was $T$. harzianum $(51.9 \%)$. G. virens checked the rot incidence moderately (44.8\%).
The least disease reduction was provided by $T$. viride $(38.1 \%)$. As the incubation period increased, the severity of rot incidence was also increased. In post- inoculation treatment, all biocontrol agents tested suppressed the rot incidence in guava fruits significantly as compared to control (Table 3).

Table 3: Effect of biocontrol agents on incidence (\%) of post-harvest fruit rot in guava

\begin{tabular}{|c|c|c|c|c|c|c|}
\hline \multirow{2}{*}{ Biocontrol agents } & \multicolumn{3}{|c|}{ Pre-inoculation* } & \multicolumn{3}{|c|}{ Post-inoculation* } \\
\hline & $4 \mathrm{DAl}$ & $8 \mathrm{DAl}$ & DRI & $4 \mathrm{DAl}$ & $8 \mathrm{DAl}$ & DRI \\
\hline Trichoderma harzianum & 25.6 & 37.4 & 51.9 & 30.5 & 42.7 & 56.7 \\
\hline T. viride & 30.2 & 46.8 & 38.1 & 34.6 & 58.4 & 35.4 \\
\hline Gliocladium virens & 27.0 & 42.5 & 44.8 & 31.2 & 46.3 & 46.9 \\
\hline Chaetomium globosum & 16.1 & 25.8 & 69.2 & 19.1 & 32.7 & 62.4 \\
\hline Control & 54.7 & $\begin{array}{c}77.2 \\
\operatorname{CD}(P=0\end{array}$ & 0 & 55.5 & 85.2 & 0 \\
\hline Biocontrol agents & \multirow{2}{*}{\multicolumn{3}{|c|}{1.44}} & \multicolumn{3}{|c|}{1.72} \\
\hline Days & 0.71 & & & \multicolumn{3}{|c|}{0.92} \\
\hline Interaction & \multirow{2}{*}{\multicolumn{3}{|c|}{$\begin{array}{l}2.10 \\
3.37\end{array}$}} & \multicolumn{3}{|c|}{2.42} \\
\hline CV (\%) & & 3.37 & & \multicolumn{3}{|c|}{3.78} \\
\hline
\end{tabular}

${ }^{*}$ Figures were angular transformed before analysis; DAI = days after inoculation; $D R I=$ disease reduction index

The results on dual culture with biocontrol agents revealed that out of 4 antagonists, $T$. viride proved most inhibitory followed by $G$. virens towards mycelial growth by $C$. gloeosporioides. Similar observations on biocontrol potential of Trichoderma species and other fungi against fruit rot pathogens have been reported by various workers (Sharma et al., 2008; Joshi et al., 2016). Results similar to the present investigation were reported by CruzQuiroz et al. (2018) showing significant mycelial growth inhibition of $C$. gloeosporioides and
Phytophthora capsici by native Mexican Trichoderma strains. Further Valenzuele et al. (2015) and Maheshwari and Vidhya (2016) found $T$. viride and $T$. harzianum as the most potent bio-agents in inhibiting mycelial growth of various fruit rot pathogens. The use of $T$. viride and $T$. harzianum significantly checked the Fusarium wilt of cumin and chickpea under greenhouse and field conditions (Gangopadhyay and Ram Gopal, 2010; Khan and Gangopadhyay, 2012). 
Various modes of action of the biocontrol agents in suppressing the soil borne pathogens including Alternaria alternata, C. gloeosporioides, Fusarium species have been demonstrated. For instance, the mode of antagonism of Trichoderma and Gliocladium spp. to pathogens are known to be through competition for nutrition and space, and production of lytic enzymes, toxins and volatile substances (Agarwal et al., 2011; Khan and Gangopadhyay, 2012; Mukhopadhyay and Kumar, 2020). Trichoderma spp. are known to produce volatidle (6-pentyl $\alpha$ - pyrone and harzionalide) and non-volatile (trichodermin, suzukacillin and alamethicine) antibiotics (Joshi et al., 2016). In the present investigation, secreation of yellowish green or light brown secondary metabolites by Trichoderma spp. in growth medium was observed. Based on scanning electron microscopical investigation, Kishan et al. (2017) put the evidences of mycoparasitism of Sclerotinia sclerotiorum by Trichoderma spp.

\section{Hot water treatment}

All the hot water treatments were found significantly superior in reducing the guava fruit rot severity on 7 days of inoculation over control (Table 4). The fruits exposed to $55^{\circ} \mathrm{C}$ for $10 \mathrm{~min}$ recorded significantly lowest Colletotrichum fruit rot but it was at par to $55^{\circ} \mathrm{C}$ for $5 \mathrm{~min}$ or $50^{\circ} \mathrm{C}$ for

\section{REFERENCES}

Agarwal, T., Malhotra, A., Trivedi, P.C. and Biyani, M. (2011) Biocontrol potential of Gliocladium virens against fungal pathogens isolated from chickpea, lentil and black gram seeds. Journal of Agricultural Technology 7:1833-1839.

Alemu, K., Ayalew, A. and Waldetsadik, K. (2014) Evaluation of antifungal activity of botanicals for post-harvest management of mango anthracnose (Colletotrichum gloeosporioides). International Journal of Life Sceinces 8 : 1-6.

Anonymous (2019) Report on guava production 2018-19. National Horticulture Board, Government of India

Barnett, H.L. and Hunter, B.B. (1972) Ilustrated genera of imperfect fungi. Burgess
$10 \mathrm{~min}$. The natural skin colour of fruits changed from yellowish white to dark brown with softening of underlying tissue due to high temperature. Soares-Colletti and Lourenco (2014) reported that a hot water dip of guava fruits at $50^{\circ} \mathrm{C}$ for 2 min followed by irradiation at $0.5 \mathrm{KGy}$ totally eliminated fruit decay loss caused by Colletotrichum spp.

Table 4. Effect of hot water treatment on the severity of $C$. gloeosporioides

\begin{tabular}{|c|c|}
\hline Hot water treatment & \% severity after 7 days $^{*}$ \\
\hline $45^{\circ} \mathrm{C}$ for $5 \mathrm{~min}$ & 16 \\
$45^{\circ} \mathrm{C}$ for $10 \mathrm{~min}$ & 10 \\
$50^{\circ} \mathrm{C}$ for $5 \mathrm{~min}$ & 08 \\
$50^{\circ} \mathrm{C}$ for $10 \mathrm{~min}$ & 05 \\
$55^{\circ} \mathrm{C}$ for $5 \mathrm{~min}$ & 04 \\
$55^{\circ} \mathrm{C}$ for $10 \mathrm{~min}$ & 04 \\
Control & 37 \\
$\mathrm{CD}(\mathrm{P}=0.05)$ & 2.6 \\
$\mathrm{CV}(\%)$ & 18.4 \\
\hline${ }^{*}$ Figures &
\end{tabular}

${ }^{\star}$ Figures were square root transformed before analysis

The present study concluded that the post-harvest fruit decay loss of guava could be controlled by using extracts of garlic clove, betel leaf, turmeric rhizome and neem leaf; biocontrol agents viz. $T$. viride, $T$. harzianum, $C$. globosum and G. virens, and hot water treatment at $50^{\circ} \mathrm{C}$ for 5 min. In order to prevent further advancement of diseae to a damaging level, this biocontrol consortium may be ideal to use.

\section{Publishing Company, Minneapolis,} Minnestoa, USA.

Cook, R.J. (1993) Making greater use of introduced microorganisms for biological control of plant pathogens. Annual Review of Phytopathology 31 : 53-80.

Chourasia, H.K. and Jha, G.N. (2010) Fruit rot diseases of guava and physiochemical changes in fruits under pathogenesis. Journal of Mycology and Plant Pathology $40: 432-435$.

Cannon, P.F., Damm, U, Jonston, P.R. and Weir, B.S. (2012) Colletotrichum - current status and future directions. Studies in Mycology 73 : 181-213.

Cruz-Quiroz, R.D.L., Roussos, S., Herrara, R.R., Castillo, D.H. and Aguilar, C.N. (2018) 
Growth inhibition of Colletotrichum gloeosporioides and Phytophthora capsici by native Mexican Trichoderma strains. Karbala International Journal of Modern Science 4 : 237-243.

De Silva, D.D., Crous, P.W., Ades, P.K., Hyde, K.D. and Taylor, P.W. (2017) Lifestyles of Colletotrichum species and implications for plant biosecurity. Fungal Biology Review 31 : 155-168.

Dissanayake, M.M.C., Dahanayaka, V.S. and Ranasinghe, C. (2019) Antifungal potential of some plant extracts against Colletotriclum gloeosporioides causal organism of papaya anthracnose disease. Asian Journal of Biological Sciences 12 : 589-595.

Gangopadhyay, S. and Ram Gopal (2010) Evaluation Trichoderma spp. alongwith farm yard manure for management of Fusarium wilt of cumin (Cuminum cyminum L.) Journal of Spices and Aromatic Crops 19 : 57-60.

Jat, B.L., Gour, H.N. and Sharma, P. (2008) Efficacy of phytoextracts and bioagents against Colletotrichum gloeosporioides causing banana (Musa paradisiaca) fruit rot. Journal of Mycology and Plant Pathology 38 : 635-638.

Johnny, L., Yusuf, U.K. and Nulit, R. (2010) The effect of herbal plant extracts on the growth and sporulation of Colletotrichum gloeosporioides. Journal of Applied Biosciences 34 : 2218-2224.

Joshi, D., Singh, P., Singh, A., Lal, R.J. and Tripathi, N. (2016) Antifungal potential of metabolites from Trichoderma sp. against Colletotrichum falcatum causing red rot of sugarcane. Sugar Technology 18, 529536.

Johnson, K.A. (2018) Characterization and fungicide efficacy of North Carolina Colletotrichum populations causing Glomerella leaf spot and fruit rot on apple. Phytopathology 108 : S1.298. ISI, Google Scholar

Khan, M.A. and Gangopadhyay S. (2012) Effect of soil inhabiting microflora against Fusarium oxysporum f.sp. ciceri, incitant of wilt in chickpea. Journal of Mycology and Plant Pathology 42 : 341-346.

Kishan, G., Kumar, M., Tiwari, R. and Sharma, P. (2017) Deciphering the mechanism of mycoparasitism of Sclerotinia sclerotiorum by Trichoderma. spp. International Journal of Pure and Applied Bioscience 5 : 1246-1250.

Soares-Colletti, A.R. and Lourenco, S.A. (2014) Effect of temperature, wetness duration and cultivar on the development of anthracnose in guava fruits. Summa Phytopathologia 40 : 307-312.

Lakpale, N., Khare, N. and Thrimurty, V.S. (2008) Evaluation of botanicals for antimicrobial properties. Journal of Mycology and Plant Pathology 38 : 614617.

Li, J., Sun, K., Ma, Q., Chen, J., Wang, L., Yang, D., Chen, X. and Li, X. (2017) Colletotrichum gloeosporioides contaminated tea infusion blocks lipid reduction and induces kidney damage in mice. Frontiers in Microbiology 8 : 20892097.

Maheshwari, U. and Vidhya, K. (2016) Antagonistic effect of Trichoderma species against various fruit pathogens. International Journal Pharmaceutical Science Review Research 36 : 11-19.

Munir, M., Amsden, B., Dixon, E., Vaillancourt, L. and Gauthier, N.A.W. (2016) Characterization of Colletotrichum species causing bitter rot of apple in Kentucky orchards. Plant Disease 100 : 2194-2203.

Mukhopadhyay, R. and Kumar, D. (2020) Trichoderma : a beneficial antifungal agent and insights into its mechanism of biocontrol potential. Egypatian Journal of Biological Pest Control 30:133- https :/doi.org/10.1186/s41938-020-0333-x

Nane, Y.L. and Thapliyal, R.N. (1979) Fungicides in plant disease control. Oxford and $\mathrm{IBH}$ Publishing Co., New Delhi, 11 ed, pp. 7-10.

Nur Fatimma, A., Munirah, M.S., Sharifah, S.M., Najihah, A. and Nur Ain Izzati, M.Z. (2018) Efficacy of Allium sativum extract as post-harvest treatment of fruit rot of mango. Plant Pathology and Quarantine $8: 144-152$.

Ozbay, N., Newman, S.E. and Brown, W.M. (2014) The effect of Trichoderma harzianum strains in the growth of tomato seedlings. Acta Horticulture 635 : 131135. 
Pan, S. and Bhagat, S. (2007) Antagonistic potential of Trichoderma and Gliocladium spp. from West Bengal. Journal of Mycology and Plant Pathology 37 : 235239.

Panchal, D.G. and Patil, R.K. (2009) Eco-friendly management of fruit rot of tomato caused by Alternaria alternata. Journal of Mycology and Plant Pathology 39 : 6669.

Ray, S.K., Jana, M., Maity, S.S., Bhattacharya, R. and Khatua, D.C. (2007) Fruit diseases of guava in West Bengal. Acta Horticulture 73 : 525-531.

Shishido, M., Miwa, C., Usami, T., Amemiya, Y. and Johnson, K.B. (2005) Biological control efficiency of Fusarium wilt of tomato by non-pathogenic $F$. oxysporum FO-B2 in different environments. Phytopathology 95 : 1072-1080.

Sharma, R.N., Maharshi, R.P. and Gaur, R.B. (2008) Biocontrol of core rot in kinnow fruits with bioagents including an unrecorded genus of yeast (Sporidiobolus pararoseus). Journal of Mycology and Plant Pathology 38 : 211215.

Singh, A., Verma, K.S. and Mohan, C. (2008) Prevalence of anthracnose of guava in Punjab and its management. Journal of Mycology and Plant Pathology 38 : 245248.

Singh, P. (2011) Integrated management of storage anthracnose of mango. Journal of Mycology and Plant Pathology 41 : 6366.

Soares-Colletti, A.R. and Lourenco, S.A. (2014) Effect of temperature, wetness duration and cultivar on the development of anthracnose in guava fruits. Summa Phytopathologia 40 : 307-312.

Shinde, R.P., Barhate, B.G and Musmade, N.A. (2016) In vivo efficacy of garlic extract and yeast for the control of post-harvest diseases of mango and papaya. International Journal of Plant Protection 9 : 632-634.

Tasiwal, V., Benagi, V.I., Hegde, Y.R., Kamanna, B.C. and Naik, K.R. (2009) In vitro evaluation of botanicals, bioagents and fungicides against anthracnose of papaya caused by Colletotrichum gloeosporioides (Penz.) Penz. and Sacc. Karanataka Journal of Agricultural Science 22 : 803-806

Valenzuela, N.L., Angel, D.N., Ortiz, D.T., Rosas, R.A., Garcia, C.F.O. and Santos, M.O. (2015) Biological control of anthracnose by post-harvest application of Trichoderma spp. on maradol papaya fruit. Biological Control 91 : 88-93.

Woo, S.L., Scala, F., Ruocco, M. and Lorito, M. (2006) The molecular biology of the interactions between Trichoderma spp., phytopathogenic fungi and plants. Phytopathology 96 : 18-185. 